\title{
Networking for Peace: A Case Study of the Asian Muslim Action Network (AMAN)*
}

\author{
Mohamad Fikri Pido \\ Asian Muslim Action Network (AMAN), Bangkok-Thailand. \\ Email: fikri.fido@yahoo.com
}

\begin{abstract}
Since its inception in 1990, Asian Muslim Action Network (AMAN) was an endeavor to bring and link all Muslim and non Muslim as well, both individual and groups, in Asia to respond and meet the challenges faced by the community in the region. As a Muslim organization, AMAN bases itself on fundamental Islamic teachings based on the Quran and intra and inter-faith element has been essential in AMAN's activities for the past 20 years. With this paper, the author examines AMAN's experience on 3 issues. First, the importance of Islam through its faith based organization to look and work for peace of all mankind. In this part, Islam 'seems' universal for peace. Second, meaning of peace. There can be different faces of peace depending on the context we face. Thus, question of 'what is peace' needs a modification to be "what does it mean to be Peaceful?" Lastly, the challenges for faith based organization to set up inter-faith cooperation in working toward the mutually desired situation that enables peace to foster.

Keywords: faith based organization, peace, conflict, inter-faith cooperation.
\end{abstract}

\section{ABSTRAK}

Sejak didirikan pad atahun 1990, Asian Muslim Action Network (AMAN) berupayamembawa dan menghubungkan Muslim dan nonMuslim, baik secara individual maupun kelompok, di Asia untuk merespons pelbagai tantangan yang dihadapi masyarakat di wilayah Asia. Sebagai sebuah organisasi Muslim, AMAN mendasarkan diri pada ajaran dasar Islam yang berasal dari Qur'an, dan elemen hubungan intra dan antar keyakinan sangat penting bagi aktivitas AMAN dalam 20 tahun terkahir ini. Dalam tulisan ini, penulis mencoba menjawab mengkaji pengalaman AMAN dalam tiga hal pokok. Pertama, pentingnya Islam bagi organisasi ini dalam melihat dan mengkaampanyekan perdamaian untuk semua. Kedua, makna perdamaian. Ketiga tantangan-tantangan yang dihadapi oleh organisasi keagamaan untuk melakukan kerjasama antaragama guna mencapai situasi yang diinginkan semua pihak serta memungkinkan untuk mendorong terjadinya perdamaian.

Kata kunci: organisasi keagamaan, perdamaian, conflik, kerjasama antaragama.

\section{INTRODUCTION}

The special report of United States Institute of Peace in August 2012 covers three important points. ${ }^{1}$ One, the field of religious peace building has grown significantly in recent decades both in quantity and quality. Second, Faith Based Organizations (FBOs) involved in the peace building process as a religious expression. Thus, the religious values and principles are essential in the process. Third, there is a need to evaluate the performance 
of FBOs to meet the future challenges in peace building. In general, there are number of articles and papers that discuss both peace building in Asia and the role of faith-based organization in conflict transformation or peace building. However, there are only few numbers of studies to see the role of Asian faith-based organization especially Muslim organization in peace-building or conflict transformation. This paper aims to fill the gap of information and enrich the discussion of Muslim initiatives in peace building in Asia particularly.

Asian Muslim Action Network (AMAN) was established in 1990 by a group of Muslim scholars and social activist from Asia (Dr.

Ashgar Ali Engineer, Dr. Chandra Muzaffar, Dr. Mubarak Ali, Dr. Raisuddin, Ali Ahmed Ziauddin, the late Omar Asghar Khan, Shabry Chik, Wiriya and Mohamad Abdus Sabur) during an Asian Consultation in Chiang Mai. AMAN was formed from the process of realization that Muslim community in Asia was left behind. In the late 1980's Muslim population is large in number but there was no forum that Muslim Scholars, philanthropist and social workers in Asia could come together and shared experience, ideas and express common concerns. ${ }^{2}$ At the same time, Christian community has been active through Christian Conference for Asia (CCA) and Bishop's conference of Asia.

AMAN started with the modest initial program such as Islamic resource development, youth leadership training and networking-linking with Muslim scholars, institutions and NGOs. After 23 years, experiencing ups and downs, it is now growing as a network that brings together individuals, groups and associations of Muslims in Asia subscribing to a progressive and enlightened approach to
Islam. AMAN is also open to work with other faith communities as it aims to build understanding and solidarity among Muslims and other faith communities and develop programs that lead to people's empowerment, upholding human rights, justice and peace in the light of the Qur'anic teachings. Starting from nine people, AMAN has members now in 20 countries: covering Indonesia to Jordan, China to Sri Lanka. It begins as the Muslim initiatives, AMAN now is growing to go beyond Muslim organizations to be the interfaith cooperation for peace and justice. This paper highlights the efforts of AMAN as faith-based organization in the peace building process throughout region.

\section{CONFLICT TRANSFORMATION IN MULTICULTURAL ASIA}

To understand the conflict in Asia, it is imperative to understand that Asia is a multicultural society. Historically, it is a home of many religions and traditions which has built many civilizations in the human history. On the present day, it has been the fastest changing region in the last century and the beginning of this century. The Asian people are deeply cultural in the mind set. Thus this rapid change has affected the people of Asia in many different ways.

Like in other part of the world, one can learn the conflict in Asia by looking at the history of colonization in the region. Many nations in Asia were colonized by the Europeans in one form or the other. India, Pakistan, Malaysia, Indonesia, Vietnam, Cambodia, the Middle East and many more were colonized. Some countries were even creation of the colonial masters such a Palestine, IndiaPakistan and so on. These colonial masters who practiced the divide and rule method 
have had a lasting effect on the thinking of many nations in Asia. This colonial legacy has played a major role in the philosophy of modern day Asia and its nation state and has played a major role in some of the worst conflicts in Asia such as India-PakistanBangladesh-Kashmir issue, the southern Thailand issue, the Aceh issue, and the list goes on. These also result in an ill-defined concept of identity which have played havoc to the social harmony for a healthy and peaceful life among its people. For example, although the people of southern Thailand and northern Malaysia share the similar language, religion, culture, identity and even family tree they are separated by a border that they did not draw. Furthermore the people of southern Thailand do not share any of these similarities with people of people in the north. Therefore, it is natural for them to have problems of integration which has been made worst with the current conflict in the area. So the formation of a national identity becomes difficult in an unnatural demarcation put there by colonial powers. The same situation can be seen in the people of Papua in Indonesia and Mindanao in Philippines. All these factors contribute to the vulnerability of conflict in Asia with the current economic turmoil, the incidence of conflicts is on the rise.

Religious discourse can be another important point to see the conflict. Many have fueled both intra and inter-religious hatred. Thus a lot of the conflict in the region are also fueled by religious fervor of some people who may have certain interpretation of religion. This is very prevalent in Islam. An example of this is the violence using the banner of Jihad fueled by the religious teaching of some of the people who believe in their God-given rights to govern in certain ways. Some opportunists people also try to use religion to gain power over their people or to fuel insurgency.

Asia has been the battle ground for most of the conflicts the world has been witnessing. Most of the conflicts are intra-state with the wide range of types from horizontal ethno religious conflict to self-determination conflict. Conflicts are not always bad only those with violent that are destructive. Lederach explains that "Conflict happens. It is normal and it continuously present in human relationship. Change happens as well. Human community and relationship are not static but ever dynamic, adapting and changing. Conflict is normal in human relationship, and conflict is a motor of change." Having explained all above, there is a huge need to address and transform conflicts to be constructive to bring development.

The notion of conflict transformation is to look at and understand the conflict comprehensively. This concept was firstly introduced by John Paul Lederach after he was challenged on his firsthand experience in Latin America conflict, he re-questioned the concept of conflict resolution to address the reason why conflict exist. Thus he defines conflict transformation as the concept to envision and respond to the ebb and flow of social conflict as life-giving opportunities for creating constructive change process that reduce violence, increase justice in direct interaction and social structures, and respond to real life problems in human relationships. He also speaks of conflict transformation as a holistic and multi-faceted approach to managing violent conflict in all its phases. The term signifies an ongoing process of change from negative to positive relations; behavior, 
attitudes and structures. ${ }^{3}$ The integrated approach to peace building must take into account the complex and multi-dimensional nature of the human experience and rely on broad social participation. "A sustainable transformative approach suggests that the key lies in the relationship of the involved parties, with all that the term encompasses at the psychological, spiritual, social, economic, political and military levels." ${ }^{4}$ Cultivating an "infrastructure for peace building" means that "we are not merely interested in 'ending' something that is not desired. We are oriented toward the building of relationships that in their totality form new patterns, processes, and structures." Many scholars use the term peace building as an equal to conflict transformation like others use the term peace-making for conflict resolution.

Religious engagement in the promotion of peace can be seen in two things, activities which are an 'ad hoc and sporadic' basis and program that part of the strategic process. I shall not limit the discussion to any of those rather I shall try to see both in the form of programs undertaken by AMAN in the peace building process which covers broader spectrum and aims to bring change in the personal, relational, structural and cultural levels. Scrutinizing the role of AMAN in the process of peace building in Asia, I come not only to see the intersection of Islam and peace but also to realize that the socio-religious interpretation plays critical role in producing ideas and strategies to bring peace. This interpretation forms the value of the foundation to bring and sustain the efforts.

\section{DRAWING INSPIRATION FROM ISLAM}

Islam has been the greatest inspiration for AMAN in its mission. Al Quran and the life of Prophet Muhammad bring various inspirations to work for peace and justice. Al Quran as the holy book in Islam has numbers of verse which promotes peace and justice. It is important to note that as the main reference of the Muslim, Al Quran ideally serves as the basic guidance for all their undertakings. Therefore, all Muslim should act and behave peacefully in their life.

In the relation with Islam and its source, AMAN labels themselves as the progressive Muslim who read 'critically' to the interpretation of the text of sources in Islam. In this part, I am looking at the progressive Muslim as the social interpretation to portray the relation between Islam and the call for Peace. Through the glass of Progressive Muslim we can find two things: First, the argument to explain that Islam advocates peace for all mankind regardless their sex, faith, race, etc. In other word, peace is universal. Second, the idea about action to bring peace is equally important to any talks about peace.

I still reserve a room for doubt to a statement that Islam really advocates peace for all. This is due to the fact that many groups within Islam have 'unofficially' limited the scope of peace due to the theological barrier. The intra-faith conflict of syiah and sunni is an example. When the conflict occurs and takes many lives away (In the case of Indonesia, mostly syiah people), seems that Muslim group are hesitant to guarantee the right of victim to access peace and justice. Peace shall be given to all human being. It is at the heart of a progressive Muslim interpretation that every human is equal regardless their faith, sex, nationality, social status and every social attributes they have. Muslim or non-Muslim, rich and poor, has exactly the same intrinsic value. The essential value of human life is 
equally given by God. Omid Safi explains that many of those who advocate such a humanistic framework within the context of Islam have labeled themselves as progressive Muslims.

"A progressive Muslim agenda is concerned with the ramifications of the premise that all members of the human race have this same intrinsic worth because each of us has the breath of God breathed into our being: Wa nafakhtu fihi min ruhi (Quran 15:29 and 38:72). This identification with the full humanity of all human beings amounts to nothing short of an Islamic Humanism" 5

Al Quran has laid the basic tenet of peace in Islam and those can be seen through an understanding and interpretation of its verses. Among many verses, Chapter $\mathrm{Al}$ Hujurat verses 13 bring solid foundation to see the seeds of peace in a multicultural society such as Asia. It explains that the existing differences among human being are 'by design' not 'by accident' that god gave to be accepted.

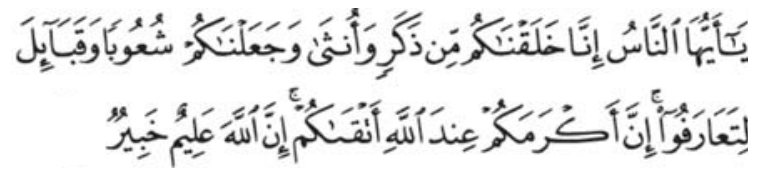

[49:13] "O mankind, indeed We have created you from male and female and made you peoples and tribes that you may know one another. Indeed, the most noble of you in the sight of Allah is the most righteous of you. Indeed, Allah is Knowing and Acquainted." 6

This verse asserts that the most pious person is the one who prioritize cooperation over hostility. Despite the fact that humans are born with many differences in color, race and sex, God command all people to know each other to understand the difference. Pluralistic society of Asia can lead to conflict which often assumes violent forms. In this regard, AMAN started as Muslim initiatives to accept pluralism and to promote it in the interest of peace and harmony.

Through the lens of progressive Muslim, I also argue that practices are equally important to thoughts. Both vision and activism are necessary to walk hand in hand. A reflection of being Muslim has to be manifested in striving peace and a just society. There are two elements for a Muslim to be called progressive according to Dr. Asghar Ali Engineer. First, grounded in the Quranic values of truth (haq), justice ( $a d l$ ), compassion (rahman), wisdom (hikmah). Second, does service to others rather being served by others. ${ }^{7}$ Safi, in his article, reaffirm that the defining characteristic of progressive Islam today is the engagement with the variety of Islam and modernity, plus an emphasis on concrete social action and transformation. To me, the word 'Action' in the AMAN names stands as reminder that the network does exist to create actions.

Islam brings inspirations through the process of interpretation. This process of interpreting religious text like Al Quran to draw inspirations to bring peace is one among the key strategy how AMAN keep its identity as Muslim initiatives.

\section{A ROADMAP TO PEACE: IDEAS AND STRATEGIES}

In this part, I shall discuss the key concept of peace and its relations with justice and the strategies in AMAN's involvement in the peace building. AMAN was established in 1990 to fill the vacuum of common forum for Muslim community in Asia. But in 2001, 
AMAN was 'reborn' from the situation of xenophobia especially Islamophobia. This can help us to see the different context AMAN has been facing since its inception. It is also imperative to see how the dynamic of the understanding of peace itself. Peace is the center of AMAN's activities and that has been reflected in the themes of The Four AMAN assemblies: Culture of Peace in 2000, The New Vision for Peace in 2003, Reform and Resistance in the Quest for Peace in 2006, and Multi-Culturalism and Global Peace in 2011

AMAN does not view peace as the goal alone but rather the journey itself. Peace is an important point to be achieved despite the journey toward peace can be misleading. As Johan Galtung classified peace into negative and positive peace, I see how the implication of this classification has led to an important question that is it peace or to be peaceful that matters? Some people justify taking a violent action to bring peace. To be peaceful is to maximize the effort of using non-violent actions for peace. Among few other elements, Non Violent and Inter-Faith has been the strong characteristic of AMAN's activities.

Acting as Non Violent movement

"Non violent action is a technique by which people who reject passivity and submission, and who see struggle as essential, can wage their conflict without violence. Non violent action is not an attempt to avoid or ignore conflict. It is one response to the problem of how to act effectively in politics, especially how to wield powers effectively."

Gene Sharp

Many scholars have discussed the nonviolence in Islam both theoretically and practically. Mohammed Abu Nimer in his book Nonviolence and Peace Building in Islam: Theory and Practice explains that nonviolence is strongly embedded in Islamic values and traditions. The interesting point about his classification of Muslim scholars/ actors in the conflict was the strong emphasis that not only there is a good and solid foundation for a non-violent movement in Islam but a relatively high possibility to undertake the movement. The example of Abdul Ghaffar Khan and his "Army of God" in the struggle against British occupation is a clear example how the core values of Islam such as Amal, Yakeen and Mahabbat are essentials in the non violent movement. Khan Abdul Ghaffar Khan once said:

"I am going to give you such weapon that the police and the army will not be able to stand against it. It is the weapon of the Prophet, but you are not aware of it. That weapon is patience and righteousness. No power on earth can stand against it. "9

We often see the violent and non violent elements in situation where injustice and oppression do exist. In such situation both can serve either a form of self defense or strategy to address the existing oppression or injustice. In this regard, AMAN believes that peace can not be separated from justice. The existence of unjust system and inequalities in the society contributes to the eruption of many violent conflicts. There will be no peace without justice. Chandra Muzaffar uses the term global justice to endorse the removal of unjust system which operates through aggression, oppression and hegemony in order to create a global peace. The strategies to bring justice have to be consistent with the basic intention to create peace. The need to address and oppose the unjust 
system or oppressive situation is equally important to the need to be non-violent. Non violent is not only a strategy but a basic need for every one because to be human is to be non-violent. ${ }^{10}$ Dr. Engineer has considered both as the essential elements in Islamic Ethic. On the establishment of just society, he explains:

The emphasis of Islamic teachings is not personal salvation but establishment of a society that is just and free of zulm (oppression). Here we will like to deal with this aspect of Islamic ethic in greater detail, as it is most central to Islam. The Qur'an lays great emphasis on 'adl (justice). It is the central value in the Islamic ethic. The Qur'an says that "Be just; it is closest to being pious." (5:8). Thus in Islam there is no concept of piety without being just. ${ }^{11}$

Affirming the using of non-violent means in the process of achieving just-society, he later argues:

... This is further reinforced by Allah's own attributes of being Merciful and Compassionate on the one hand, and repeated assertion by the Qur'an of the concept of ihsan (doing good to others). Thus it will be seen that the Islamic scripture does not morally approve even retaliatory violence which has at least some justification ... At the level of the value Qur'an upholds non-violence and exhorts Muslims to use wisdom and benevolence (hikmah and ihsan) while dealing with others.

Inter-Faith element has been very essential in the peace building activities carried out by Faith-based organization like AMAN. This is not only to show that all religions share the same values to create peace but also a serious need to have a common platform that all faiths can join hands to bring peace. AMAN has been very active in organizing series of Inter-Faith dialogue or consultation related to peace issues regionally or internationally. In the year of 2000, AMAN initiated the international Inter-Faith Peace Forum prior to AMAN Assembly to enrich one another with a wider vision and unique experience in responding to any threat to global peace.

Interreligious dialogue builds respect for other religious traditions. Based on knowledge it leads to friendship and cooperation. Leading to dialogue of life or action for addressing common problems such as poverty, war and national disasters etc. Thus dialogue is an essential strategy for meeting, understanding, valuing, learning and living together in peace. $^{12}$

Since 2005, AMAN with the support of other faith organizations such as The Catholic Agency For Overseas Development (CAFOD), American Friends Service Committee (AFSC) of Religious Society of Friends (Quaker) and Diakonia, an international development organization with Christian values, has been organizing capacity building training as part of Peace Educations program of AMAN. Peace Education aims to offer short courses on peace studies and conflict transformation, action research, advocacy and networking skills. In the long journey to bring peace, peace education is seen as a potential venue for collective selfreflection, self-actualization and human and social development. The pedagogical mission of Peace Education is the movement from a culture of distrust and violence toward a culture of Peace. The involvement of other faith in peace education can be seen in the number of participants who attended the 
course. Since 2005-2013, two annual programs consists of the three weeks course of Peace Studies and Conflict transformation and Youth for Peace program were attended by $43 \%$ of non Muslim participants coming from various Asian countries and beyond. In 2013, a former Christian Peacemaker Teams (CPT), Lorin Peters, has voluntarily assisted the Peace Studies and Conflict Transformation program. During the three weeks course, he has shown that it is imperative to 'walk' the 'talk' of being 'Children of God', Christian and Muslim can live and work hand in hand for the common goal of peace. This form of collaboration serves two important points. First, interfaith initiatives in peace building have shifted from the theoretical to practical and real cooperation. Second, interfaith initiatives can be undertaken by individuals and ordinary people.

The interfaith initiatives can serve both direct and indirect intervention to a particular conflict as Lederach explains that Interreligious dialogue creates possibilities to enhance cooperation between groups and communities divided by conflict. It could rebuild the emotional and structural relationships between parties through three ways: ${ }^{13}$

1) Building long-term relationships by addressing causes underlying the conflict. 2) Establishing "infrastructure for peace" i.e. creation of peace processes and mechanisms for joint peace building at various levels from state house to the schools. 3) Building "Peace Constituency" employing local/indigenous processes and cultural methods and initiatives relevant to local contexts.

This process of collaboration as an interfaith initiative has strengthened AMAN capacity not only to see but also to practice the role of religion in the peace-building and more importantly to be more systematic than ever. Katrien Hertog affirms this situation in her book of In The Complex Reality of Religious Peace-building:

"Since 2000... one has observed the emergence of a distinct field of study known as "religious peace-building."... At the same time, religious peace-building is also gaining international momentum as a movement from the local level to the global level. In recent years, religious peace-building initiatives have become more visible, more urgent, more numerous, and more recognized. ... They increasingly develop an intentional, systematic, and proactive approach to peace-building, often in cooperation with other religious or confessional organizations." ${ }^{14}$

Although AMAN has formed numbers of cooperation with other faith and non-faith based institution in promoting peace it does not eliminate the identity of AMAN as the Muslim Peace groups with the reflection of Islamic traditions. Regarding the increasing number of Muslim peace groups working in conflict zone, US Institute wrote in the special report:

Many Muslim peace groups have emerged in conflict zones to promote Islamic principles of nonviolence and peace building, emphasizing the pursuit of justice; doing good; the universality and dignity of humanity; the sacredness of human life; equality; the quest for peace (individual, interpersonal, communal, regional, and international); peacemaking through reason, knowledge, and understanding; creativity; forgiveness; proper deeds and actions; responsibility; patience; collaborative actions and solidarity; inclusivity; diversity; pluralism; and tolerance ${ }^{15}$

This report also validates AMAN's works 
to portray the role of religion in peace building: ... and the Asian Muslim Action Network in Thailand demonstrates that Muslim civil society actors are important agents of change operating within an Islamic paradigm in their communities. ${ }^{16}$

Besides the above two major defining characteristics of AMAN in the peace building there are also few minor characteristic that can be identified

\section{CROSSING THE LINE OF 'FRIEND' AND 'ENEMY':}

The issue is originally coined by Prof. Chaiwat Satha Anand in his article 'Crossing the Enemy's line: Helping Others in violent Situation Through Non-Violent Action' to explain the importance of removing the power of hatred which fuels the fire of violence. ${ }^{17}$ The concept of 'friend' and 'enemy' in this context was introduced by Carl Schmitt in his book of The Concept of The Political. The concept of 'line' originally is to draw a separation between 'friend' and 'enemy' that can be on the basis of religion. Violent conflict often inherits the 'imaginary line' between the two opposing groups 'friend' and 'enemy', this line will also affect to the process of association and disassociation. ${ }^{18}$ The conflict in Rakhine State of Myanmar which was originally between Rakhine and Rohingya has transformed to a Buddhist versus Muslim conflict. Many people have seen the same case in the conflict of Southern Thailand although there are various different characteristic.

Although the root cause of conflict in Southern Thailand is not religion, it has been used as a dividing factor between Buddhist and Muslims. As a result, belief takes precedence over the truth which leads to prejudice and hatred and subsequently the polarization and collapse of communities. ${ }^{19}$

In many programs for such related conflict, AMAN has tried to break the line in order to bring together the 'friend' and the 'enemy'. This requires huge effort and full strategy to undergo this path. In line with Chaiwat's point of the lesson learnt from this strategy, I see that the 'line', 'friend' and 'enemy' are socially constructed to prolong the conflict by the institution, memories, perception or interpretation. The line is used the keep both sides separately and provide a single perspective to see conflict and the 'other'. There is no alternative to see from different angle as they are conditioned to be treated as 'enemy' and treat others as 'enemy'. The language of violence is often spoken to the 'enemy' not 'others'. ${ }^{20}$ Crossing the 'line' will open the space for both to see, understand and experience the context of each other from their own original perspective.

\section{AVOID THE IMPERIALIST NATURE OF PEACE BUILDING}

There is a hypothesis that Peace building has the nature of imperialistic. ${ }^{21}$ When a violent conflict occurs, many actors intervened with the prescription in their hand. We often find that there is such 'universal prescription' to all type of conflicts. AMAN works to nurture the seeds for peace initiatives to grow from within. Peace building works to overcome the broken relation and feelings which requires the deep understanding of different context and situation people are facing. "Peace building is an art. Any attempt to build peace or overcome a broken relationship, it requires a certain act at a 
certain moment. This supports the idea that peace building is a normative. An ethical and normative approach is necessary." ${ }^{2}$

AMAN works to train and empower this people through the training such as The Three Weeks School of Peace Studies and Youth for Peace so they could develop new ideas and start to involve with the peace building process in their respective context.

\section{EMPOWER THE MOST VULNERABLE}

Children and women have been the most vulnerable victims in many conflicts. Within the limitation of capacity, it is necessary to make the priority of the target group. In 2004, a specific consultation process for peace led by Youth community in Southern Thailand was organized by AMAN through its umbrella organization Asian Resource Foundation (ARF) in cooperation with UNICEF. This consultation was held in two levels: local schools and community throughout five provinces namely Pattani, Yala, Naratiwat, Songkhla and Satun. This program allow both Young people from both Community, Buddhist and Muslim to listen to each other's stories, understand their feelings and most importantly they could voice their rights as Children and Youth regardless their religion and race. The example shows that there is always a way to find the common thing in the differences.

Women's experience of armed conflict is different from men. We often to see the vulnerability of the women during those conditions because they not only have to overcome trauma and care for their families and communities but also provide a livelihood for their families as they are often left 'half widowed'. Their stories need to be heard. In April 2012, AMAN brought to- gether eight women, two from Southern Thailand and three from Mindanao and Aceh who are either affected by armed conflict and/or work for women and children affected by the same in a workshop. During two weeks program, they have visited and met victims of the conflict in Aceh and Southern Thailand. This workshop enabled them to share their stories and synthesize a learning experience in order to gain knowledge and strengthen their selves, communities and beyond for peace building and sustained harmony. Despite many challenges such as language barrier, the program has clearly sent the message to all of the participants and beneficiaries that they are not alone. They have gained their spirit to look at to the future with a confident.

\section{CONCLUSION}

For the last 23 years, AMAN has sustained its effort not only to address but also to respond the numerous issues faced by the people in Asia. Reflecting from the past, AMAN as Muslim initiatives needs to see the future challenges which I have mentioned some in the following conclusion.

First is collaboration. In peace work there is no scope of competition except the competition of excellent. Collaboration is essential in the journey toward Peace. What we have reached is still far away from the ideal situation. Cooperation for peace needs to have two elements: Inter and Intra-Faith element. While the first has been well addressed and practiced, the latter needs to have special attention as the trend of violent conflict within a single faith increases drastically. AMAN and other Muslim organizations bears moral obligation to bring all element within Islam to address the sectarianism 
within Islam. There is also a need to have strategic collaboration with other related sectors like human rights, economic, military and others both in the government or non governmental bodies.

Second is institution. Despite the success to survive as a network, AMAN needs to reevaluate and rethink its self as an institution. Two important home works in this area. One is to empower the network. Building the network is not enough, empowering the network is highly needed for AMAN. This requires strong commitment from both, AMAN and its networks. And there should be great designs which enable the empowerment to be part of the strategic process. Two is to prepare for the future. Regeneration is essential for AMAN to ensure the participation of larger community. This is also to enable the completion of the unfinished task toward peace.

Third is evolution. AMAN has evolved from the network of people and institution to the network of ideas, hopes and dreams. There are two contradictory points as the result of being the 'loose' institution. In one hand, AMAN has been the effective forum for many young people to express what they think about the world. Through this network, this young people try to reach out their friends who have common thoughts and ideas for the better world even it is just a hope or dream. On the other hand, the networks seems vulnerable and reluctant with the absent of constant coordination to maintain a specific idea to be manifested in a program.

\section{ENDNOTES}

1 Hayward, Susan. Religion and Peacebuilding: Reflections on Current Challenges and Future Prospects. United States Institute of Peace Special Report. Online
Publication available on http://www.usip.org/files/ resources/SR313.pdf. p.4. Retrieved on May 24, 2013. 17.01.

2 Sabur, M. Abdus. Personal Reflections on AMAN since it's inception in 1990. AMANA. (2011).

3 Lederach, John Paul. Conflict Transformation in Protected Internal Conflicts: The Case for a Comprehensive Framework. in Kumar Rupesinghe (ed), Conflict Transformation. (New York: Macmillan, 1995), pp. 201222.

4 Lederach, John Paul. Building Peace: Sustainable Reconciliation in Divided Societies. (Washington, 1997) p.75.

5 Safi, Omar. 'What is Progressive Islam?', Online ISIM newsletter. Accessed from http://omidsafi.com/images/ stories/what_is_progressive_islam.pdf. Retrieved on May 18, 2013.

6 Sahih International English Translation of Al Quran. Accessed from http://quran.com. retrieved on May 1 , 2013.

7 Engineer, Asghar Ali. "Who is a Progressive Muslim". AMANA. (April 2011).

8 Sharp, Gene. The Methods of Non Violent Action, (Boston: Porter Sargent Publishers 1973), p. 64.

9 Easwaran, Eknath, A Man to Match His Mountain Badshah Khan: Non Violent Soldier of Islam. (USA: Blue Mountain Center of Meditation, 1984) p. 117.

10 The lecture delivered by Prof. Joseph Fernando of Assumption University of Thailand in the session of Non Violent Movement during AMAN School of Peace Studies and Conflict Transformation, Bangkok, Thailand, February, 22. (2012).

11 Engineer, Asghar Ali. Islamic Ethic. Online article from http://andromeda.rutgers.edu/ rtavakol/engineer/ ethics.htm. Retrieved on May, 23 (2013).

12 The lecture delivered by Dr. Imtiyaz Yusuf in the session of Religion, Conflict and Peace: Interreligious and Intrareligious Dialogue Dimension during AMAN School of Peace Studies and Conflict Transformation. Bangkok Thailand. February, 22 (2012).

13 Lederach, John Paul. "Conflict Transformation in Protracted Internal Conflicts." p. 270.

14 Katrien Hertog, The Complex Reality of Religious Peace building: Conceptual Contributions and Analysis. (Lanham MD: Lexington Books, 2010) p.15.

15 Hayward, Susan. Religion and Peace Building: Reflections on Current Challenges and Future Prospects..., p. 4.

16 Hayward, Susan. Religion and Peace Building: Reflections on Current Challenges and Future Prospects..., p.5.

17 Anand, Chaiwat Satha. "Crossing the Enemy's line: Helping Others in Violent Situation Through NonViolent Action" in Abdus Sabur and Lisa Schenk (ed), New Visions for Peace. (Bangkok: Asian Muslim Action Network) p. 33.

18 Schmitt, Carl. The Concept of The Political. (Chicago and 
London: The University of Chicago Press, 1976) p. 21.

19 Sabur, Ekraj. Nurturing The Seed of Peace Through Peace Education: An Experience from Southern Thailand. AMANA Magazine, Agustus (2012).

20 Carl Schmitt once mentioned that War is the existential negation of the enemy. For details read The Concept of The Political. (Chicago and London: The University of Chicago Press, 1976)

21 Read Peacebuilding: Imperialism's New Disguise? by Constanze Schellhaas and Annette Seegers. African Security Review. Institute for Security Studies

22 Tamthai, Mark. "Conflict Transformation and Peace Building' in AMAN/ARF Staff (ed), Peace and Conflict Transformation in the Age of Hegemony and Extremism. (Bangkok: Asian Muslim Action Network and Asian Resource Foundation, (2007) p. 42.

\section{BIBLIOGRAPHY}

AMAN/ARF Staff (eds). 2007. Conflict Transformation and Peace Building, Peace and Conflict Tranformation in the Age of Hegemony and Extremism. Bangkok: Asian Muslim Action Network and Asian Resource Foundation

Easwaran, Eknath. 1984. A Man to Match His Mountain Badshah Khan, Nonviolent Soldier of Islam. USA. Blue Mountain Center of Meditation.

Engineer, Asghar Ali. 2011. "Who is Progressive Muslim?", AMANA Vol. 5 No. I April 2013. Islamic Ethic (online), <http:// andromeda.rutgers.edu/ rtavakol/engineer/ ethics.htm>, May 23,

2013. On The Concept of Compassion in Islam, <http://andromeda.rutgers.edu/ rtavakol/ engineer/compassion.htm>, May 17 2013. On Developing Theology Of

Peace In Islam (online), < http://andromeda.rutgers.edu/ rtavakol/engineer/theology.htm>, May 17

Hertog, Katrien. 2010. The Complex Reality of Religious Peacebuilding: Conceptual Contributions and Analysis. Lanham, Maryland: Lexington Books.

Lederach, John Paul. 2003. The Little Book of Conflict Transformation. Pennsylvania: Good Books 1995. Conflict Transformation in Protracted Internal Conflicts: The Case for a Comprehensive Framework. in Conflict Transformation, ed. Kumar Rupesinghe, New York: Macmillan. 1997. Building Peace: Sustainable Reconciliation in Divided Societies. Washington D.C:. United States Institute of Peace.

Nimer, Mohammed Abu. 2003. Nonviolence and Peacebuilding in Islamic: Theory and Practice. Gainesville Florida: Florida University Press.

Paige, Glenn D., Chaiwat Satha-Anand (Qadeer Muheideen) and Sarah Gilliat (eds). 1993. Islam and Nonviolence. Honolulu: Center for Global Nonviolence Planning
Project Matsunaga Institute for Peace.

Sabur, M. Abdus., Schenk, Lisa (ed). 2003. New Visions for Peace. Bangkok. Asian Muslim Action Network.

Schmitt, Carl. 1976. The Concept of the Political. Chicago and London: The University of Chicago Press.

Sharp, Gene. 1973. The Methods of Nonviolent Action. Boston: Porter Sargent Publishers.

Yusuf, Imtiyaz and Campion, James. 2008. Reform and Resistance in the Quest for Peace. Bangkok: Asian Muslim Action Network

Hiariej, Erik. 2008. "Terorisme dan Individualisasi Perang." Kompas. November 6

Muzaffar, Chandra. 2011. "Fostering Intra-Faith and InterFaith Understanding in Pursuit of World Peace," AMANA Vol. 5 No. I April.

Prateek, Satya. 2012. "The Phantom of Progressive Islam: What is at Stake?" AMANA Vol. 5 No. 3. April

Sabur, Ekraj. 2012. "Nurturing The Seed of Peace Through Peace Education: An Experience from Southern Thailand", AMANA Magazine Vol. 6 No. II. Agustus

Safi, Omid. 2013. What is Progressive Islam? In ISIM newsletter (online), <http://omidsafi.com/images/ stories/what_is_progressive_islam.pdf>, May 18

Schellhaas, Constanze,. Seegers, Annette. 2009. 'Peacebuilding: Imperialism's New Disguise?' African Security Review. Vol. 18 No. 2. Pretoria (South Africa): Institute for Security Studies.

Zakaria, Fareed. 2001. "The Politics Of Rage: Why Do They Hate Us?" Newsweek. October 15 